\title{
The Role of Hybridisation in the Making of the Species-Rich Arctic-Alpine Genus Saxifraga (Saxifragaceae)
}

\author{
Jana Ebersbach ${ }^{1, *(D)}$, Natalia Tkach ${ }^{2}$, Martin Röser ${ }^{2}$ iD and Adrien Favre $^{3}$ (D) \\ 1 Saskatoon Research and Development Centre, Agriculture and Agri-Food Canada, \\ Saskatoon, SK S7N 0X2, Canada \\ 2 Institute of Biology, Geobotany and Botanical Garden, Martin Luther University Halle-Wittenberg, \\ Neuwerk 21, 06108 Halle, Germany; natalia.tkach@botanik.uni-halle.de (N.T.); \\ martin.roeser@botanik.uni-halle.de (M.R.) \\ 3 Senckenberg Research Institute and Natural History Museum Frankfurt, 60325 Frankfurt am Main, \\ Germany; Adrien.Favre@senckenberg.de \\ * Correspondence: ebersbach.jana@gmail.com
}

Received: 25 September 2020; Accepted: 20 November 2020; Published: 23 November 2020

\begin{abstract}
Evolutionary processes fuelling rapid species diversification are not yet fully understood, although their major contribution to overall patterns of plant biodiversity is well established. Hybridisation is among the least understood of these processes, despite its multifaceted role in speciation processes being widely accepted. Species of the large arctic-alpine genus Saxifraga are notorious for their ability to hybridise; however, the overall role of hybridisation and polyploidisation for the diversification of this genus remains unknown. Here, we provide a comprehensive genus-wide review of hybridisation accounts and ploidy levels. We find that the sections of Saxifraga vary greatly in their propensity to hybridise. The majority of natural hybridisation accounts are from recent localised events $(n=71)$. Hybridisation hotspots were located in the Pyrenees and the European Alps, thus contrasting with the overall distribution of species richness in the genus. Hybrids or hybrid populations are often short-lived in Saxifraga due to a multitude of reproductive barriers, most commonly low $F_{1}$ hybrid fertility. However, these barriers are not always fully effective, allowing for backcrossing and the formation of hybrid swarms. In addition, we find that the incidence of polyploidy varies widely across different sections of Saxifraga, with species-rich sections Porphyrion and Saxifraga showing divergent polyploidy proportions. Overall, we show that hybridisation and polyploidisation played differential roles in the diversification of this large genus. Nevertheless, a significant proportion of species are yet to be scrutinised, particularly among the Asian Saxifraga species, illustrating the need for systematic further study to fully unravel the role of hybridisation during the evolution of Saxifraga.
\end{abstract}

Keywords: hybridisation; polyploidy; evolutionary radiation; Saxifraga; speciation; $\mathrm{F}_{1}$ hybrid sterility

\section{Introduction}

Hybridisation, defined as the mating of members of genetically distinct populations [1,2], has historically been largely viewed as evolutionary noise (e.g., [3,4]) since $F_{1}$ hybrids are generally less viable and fertile than their parental species. However, the vast body of evidence from model systems involving hybridising species pairs clearly points to a multifaceted role of hybridisation in the process of speciation [4-6]. On the one hand, gene flow between divergent lineages (e.g., populations) may slow down, stop or reverse their ongoing differentiation. On the other hand, speciation may be accelerated by the transfer of adaptive traits via introgression; generation of new, favourable allele 
combinations; or the process of reinforcement $[6,7]$. The ultimate outcome of hybridisation strongly depends on the physiological, ecological and morphological attributes of hybrids (i.e., the extent of prezygotic and postzygotic reproductive isolation [8-11]).

In any case, hybridisation generates new combinations of parental alleles and may lead not only to intermediates of parental traits but also to transgressive ones. When fixed in a hybrid population, these traits may foster reproductive isolation from parental species, and hybrid genotypes may embark on their own evolutionary track, potentially leading up to hybrid speciation $[6,12,13]$. This process is now well-accepted to be ubiquitous among plants, with ca. $25 \%$ of plant species known to hybridise [14]. Many plant species are believed to have arisen from hybridisation (examples from 27 plant genera and 16 plant families were cited by [5]), thus demonstrating the critical role of hybridisation in speciation and evolution $[6,15,16]$. However, the frequency and significance of hybridisation as an evolutionary driver varies among taxonomic groups. An example of taxa prone to hybridisation is the tribe Poeae and relatives (temperate grasses; Poaceae Barnhart). There, patterns of cytonuclear discordance were best explained by ancient hybridisation as revealed for approximately $63 \%$ of the ca. 115 genera [17], thus supporting hybrid origin not only of genera but also of higher taxa such as tribes or subtribes.

Furthermore, hybridisation and its genomic consequences can drastically impact the ecological niches of hybrid offspring compared to their progenitors. Occupancy of a different ecological niche is expected to be important for the offspring to escape parental competition and thus for long-term survival. For example, in Helianthus L., a classic model system for interspecific hybridisation, two parental species gave rise to a salt-resistant hybrid species, which was able to conquer a new adaptive landscape compared to the parental species [18]. This system appears to be a rare instance of homoploid hybrid speciation (parents and hybrid offspring having the same ploidy level), for which only ca. 20 cases are considered to be reliably documented $[19,20]$. Whereas this mode of speciation may unfold relatively slowly (e.g., [21]), hybrid speciation may be almost instantaneous when polyploidisation occurs [22]. In fact, it is likely due to the almost immediate reproductive isolation of the offspring from their progenitors that polyploid hybrid speciation appears to be far more frequent than homoploid hybrid speciation [23-25].

Hybridisation and polyploidisation may occur anywhere, yet some habitats appear more prone to generating or sustaining hybrids. Examples include disturbed habitats in Silene L. [26] and Banksia L.f. [27] or areas characterised by ecological gradients where hybrids are more likely to find an environmental niche matching their genetic makeup (e.g., in Iris L. [28,29]). Similarly, polyploids have been shown to occur most frequently in habitats that have undergone rapid environmental changes. This is particularly evident in areas that have undergone deglaciation, such as the Arctic and some mountain systems [30-33]. For example, 78.3\% of the native Svalbard flora is made up of polyploid species [30]. However, only a few studies to date have explicitly compared the degree of polyploidy between arctic-alpine taxa and their non-arctic-alpine sister lineages. For example, in Artemisia L., a genus relatively well-represented in the Arctic, no higher proportion of polyploids was found in the arctic relatives of non-arctic lineages when using phylogenetic correction [34]. Thus, the link between glaciation and other historical factors, and polyploidy remains to be resolved. Additionally, hybridisation and polyploidisation appear to be more frequent in species-rich and rapidly diversifying groups, but the exact relationship between these processes and species richness is yet to be fully understood [7,35-37]. Unravelling the complex roles of hybridisation and polyploidisation as catalysts of diversification will require the use of a variety of integrative approaches across evolutionary scales, including in-depth investigations of individual species-rich plant groups such as Saxifraga L.

Saxifraga is considered one of the most characteristic floristic elements of the Arctic and the alpine life zones of the Northern Hemisphere [31]. The genus harbours many species that are adapted to extreme conditions, growing as high as $4507 \mathrm{~m}$ a.s.l.(above sea level) (S. oppositifolia L. [38]) and $5800 \mathrm{~m}$ a.s.l. (S. punctulatoides J.T.Pan and S. nangxianensis J.T.Pan [39]) in the European Alps in the Tibeto-Himalayan region, respectively, and as far North as $81^{\circ}$ latitude in northern Canada and Greenland (S. oppositifolia and S. hyperborean R.Brown [40]). The genus also exhibits striking levels of 
species diversity, in particular, in the southern European mountain ranges, the Caucasus, the Himalayas, and the Hengduan Mountains [39,41]. It thus lends itself well to the study of species diversification in alpine and arctic habitats. Saxifraga comprises ca. 400 to 500 species, mostly perennial and herbaceous, currently divided into at least 13 sections [42]. The genus has experienced two episodes of rapid radiations in its two largest sections: Ciliatae Haw. (ca. 175 species) and Porphyrion Tausch (ca. 90 to 112 species) [43]. Even though these independent radiations unfolded roughly around the same time (majority of speciation events $<5$ million years ago, Ma), they were driven by various combinations of factors, including different geographic (Hengduan Mountains vs. Himalayas vs. European Mountains) and biotic contexts (niche evolution vs. key innovations [43,44]).

The precise evolutionary mechanisms behind these episodes of accelerated diversification have remained unclear. For example, polyploidisation was found to be positively correlated with species richness in section Ciliatae [44]. However, whether this pattern is also true for other sections of Saxifraga has not been systematically assessed. In addition, despite having long been known to be a widespread process in Saxifraga, the role of hybridisation for the overall diversification of this large genus and its many infrageneric groups has remained unclear. Here, we provide a comprehensive review of the available evidence regarding hybridisation and polyploidy in Saxifraga, framing this information in the context of Saxifraga's evolutionary history, in order to elucidate the contribution of these processes to the species diversity of this large arctic-alpine genus.

\section{Available Studies and the Extent of Hybridisation}

Saxifraga is notoriously prone to hybridisation and accounts of hybridising Saxifraga species abound in the literature. In total, we identified more than 40 scientific articles and books dealing to a variable extent with hybrids and hybridisation in Saxifraga. However, the basis of observation and the confidence in the actual occurrence of hybridisation vary widely, with some hybrids having been recorded only a handful of times. However, in this review, we included all accounts available to us for which no reasonable doubt has been expressed (e.g., by [45-47]) other than artificial hybrids bred for the sake of horticulture. We base our phylogenetic interpretations of hybridisation processes on the most recent taxonomic treatment, developed upon a robust phylogenetic framework [42]. Even though this phylogenetic reconstruction is based on only two nuclear and one chloroplast marker(s) and not all relationships are fully resolved, this still represents the most comprehensive treatment of the genus to date. As one caveat, we refrain from drawing conclusions about infrageneric series and present all results on the level of sections and subsections.

Altogether, we recorded descriptions of and references to 84 natural Saxifraga hybrids (Table S1). Whereas the majority of hybridising species are known to cross with only a single congener, there are a handful of extremely interfertile species, potentially hybridising with up to six (S. geranioides L.), seven (S. paniculata Mill.) or even ten separate species (S. exarata Vill.). In addition, hybridisation was most often observed as currently ongoing or very recent $(n=73)$, whereas the number of reports of established hybrid species is much lower $(n=11)$. This is likely because recent hybrid populations of intermediate phenotypes can be recognised relatively easily in the wild (accounts thoroughly reviewed by [47]) whereas the detection of past hybridisation requires molecular tools (e.g., for $S$. osloensis Knaben [48,49] and for S. wahlenbergii Ball [50]). Overall, this cornucopia of available studies clearly renders Saxifraga highly suitable to investigate the mechanisms of hybridisation and its evolutionary role.

\section{Taxonomic, Geographic and Temporal Distribution of Hybridisation in Saxifraga}

The frequency of hybridisation appears to vary greatly among clades and throughout the distribution range of Saxifraga. Based on our current understanding of the infrageneric phylogenetic relationships (Figures 1 and 2), taxa of the European section Saxifraga (ca. 70 to 85 species) appear to be particularly prone to hybridisation, with at least 40 cross-fertile species pairs. Similarly, the six sections forming the sister clade to section Saxifraga (sections Cotylea Tausch, Gymnopera D. Don, 
Ligulatae Haw., Mesogyne Sternb., Porphyrion and Trachyphyllum (Gaudin) W.D.J.Koch), include many hybridising species pairs. For example, section Porphyrion boasts at least 16 recorded natural hybrids. In addition, most of the species of the European sections Gymnopera (4 species) and Ligulatae (8 species) are known to hybridise with at least one other species. In contrast, we could only find isolated, circumstantial accounts of hybridisation in sections Bronchiales DeChaine and Ciliatae (see below) and none for sections Irregulares Haw. (including Heterisia (Raf. ex Small) A.M.Johnson), Pseudocymbalaria Zhmylev, and Trachyphyllum (see below) or with monotypic section Saxifragella (Engl.) Gornall and Zhou-Xin Zhang.

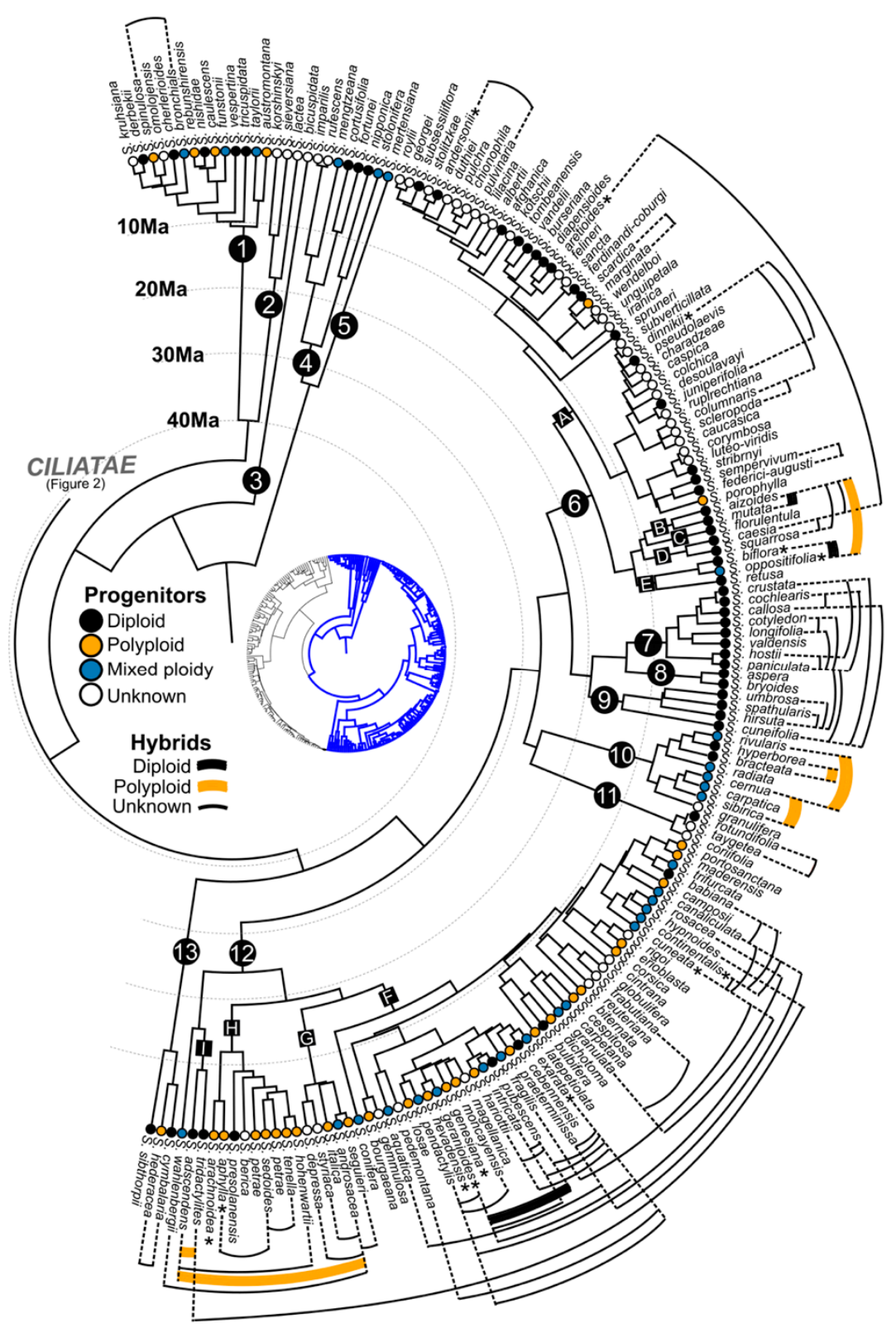

Figure 1. Time-calibrated phylogenetic tree of the genus Saxifraga (modified from [51]) excluding section Ciliatae (detailed in Figure 2): sections are indicated with black circles on branches leading to their respective crown nodes and are numbered as follows: 1. Bronchiales, 2. Pseudocymbalaria, 3. Saxifragella, 4. Irregulares, 5. Heterisia, 6. Porphyrion, 7. Ligulatae, 8. Trachyphyllum, 9. Gymnopera, 10. Mesogyne, 11. Cotylea, 12. Saxifraga and 13. Cymbalaria. Subsections are indicated by black squares and white letters on branches as follows for sections Porphyrion (A. Kabschia, B. Mutatae, C. Florulentae, 
D. Squarrosae and E. Oppositifoliae) and Saxifraga (F. Saxifraga, G. Androsaceae, H. Arachnoideae and I. Tridactylites). The ploidy level of each species is indicated by coloured circles at the terminal nodes (black: diploids, orange: polyploids, blue: several ploidy levels whether or not including diploids, and white: unknown ploidy). Arcs connecting terminal nodes represent possible ancient or current hybridisation events described in the literature. The ploidy level of hybrids, if known, is shown as coloured arcs (thick black: diploids and thick orange: polyploids). Asterisks next to species names indicate hybridisation with a species not included in our tree.

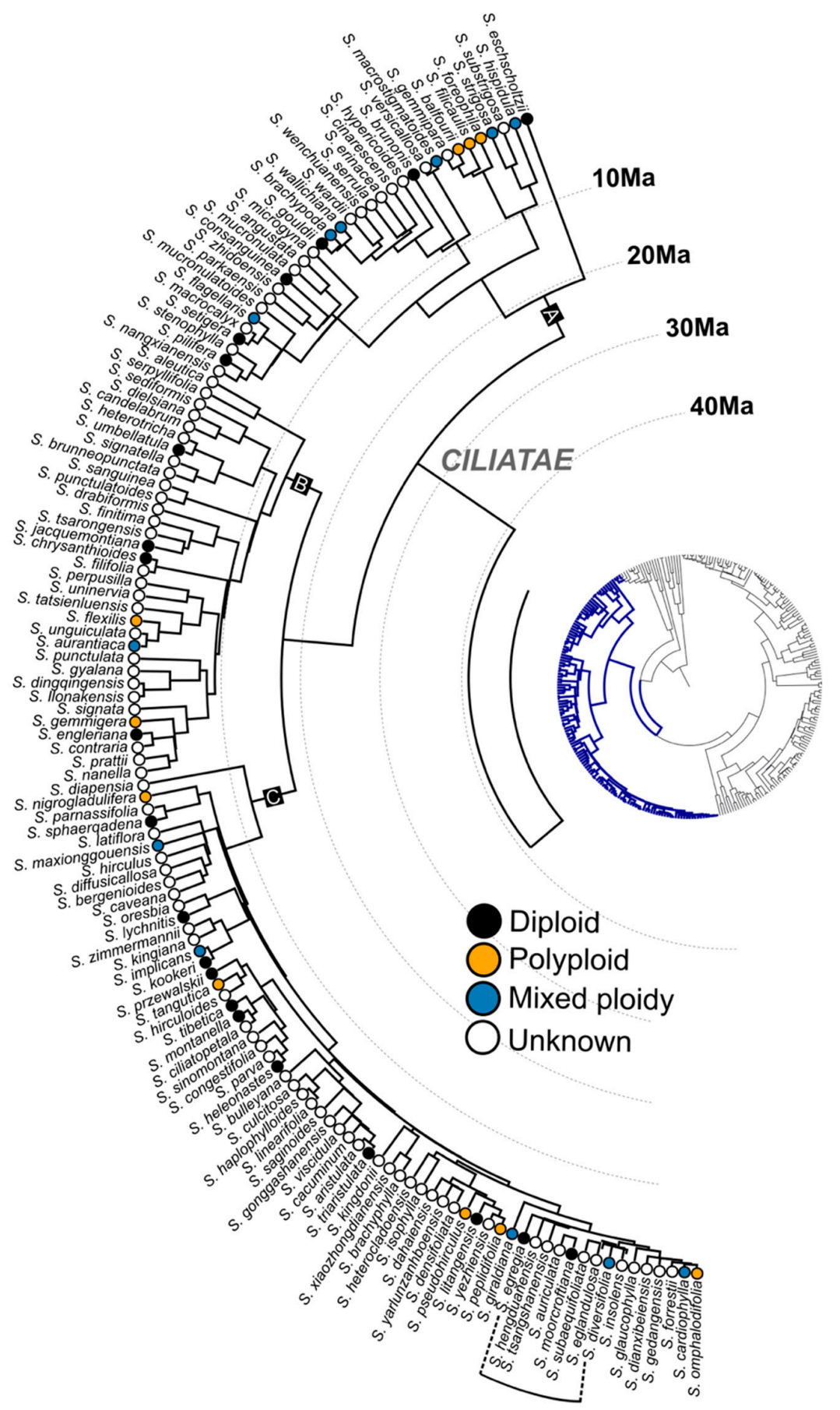

Figure 2. Time-calibrated phylogenetic tree of Saxifraga section Ciliatae continued from Figure 1 (modified from [51]): this section comprises three main clades indicated by white squares and letters on branches which include the following subsections: A. Cinerascentes, Flagellares, Gemmiparae and Hemisphaericae; B. Rosulares and Serpyllifoliae; and C. Hirculoideae. Colour coding is as in Figure 1. 
Many of these natural hybrids are restricted to extremely narrow distribution ranges, such as single mountain tops. Most recent Saxifraga hybridisation zones were reported from major European mountain systems, for example, the Pyrenees and the European Alps ( 24 and 19 hybridising species pairs, respectively; Figure 3). Furthermore, hybridisation events among Saxifraga species were particularly commonly detected in Spain (N Spain excluding the Pyrenees: 11 hybridising species pairs). We also found evidence of hybridisation events for the British Isles, the Balkan Peninsula, the Caucasus Mountains and the Himalayas, albeit with much lower frequency ( $<5$ hybridising species pairs each). Finally, relatively isolated hybridisation events have been reported from the Scandes, central Germany (Harz), the Carpathians, Morocco, Turkey, the Ural Mountains and Siberia. Strikingly, relatively few recent hybridisation events were recorded from Scandinavia and/or the Arctic $(n=1)$, but six out of 11 established hybrid species occur there. Even though it is almost impossible to know precisely where more ancient hybrid speciation took place, some of these hybrid species have extremely narrow distribution ranges (e.g., S. opdalensis Blytt and S. svalbardensis Øvstedal), which also likely represent their place of origin [30].

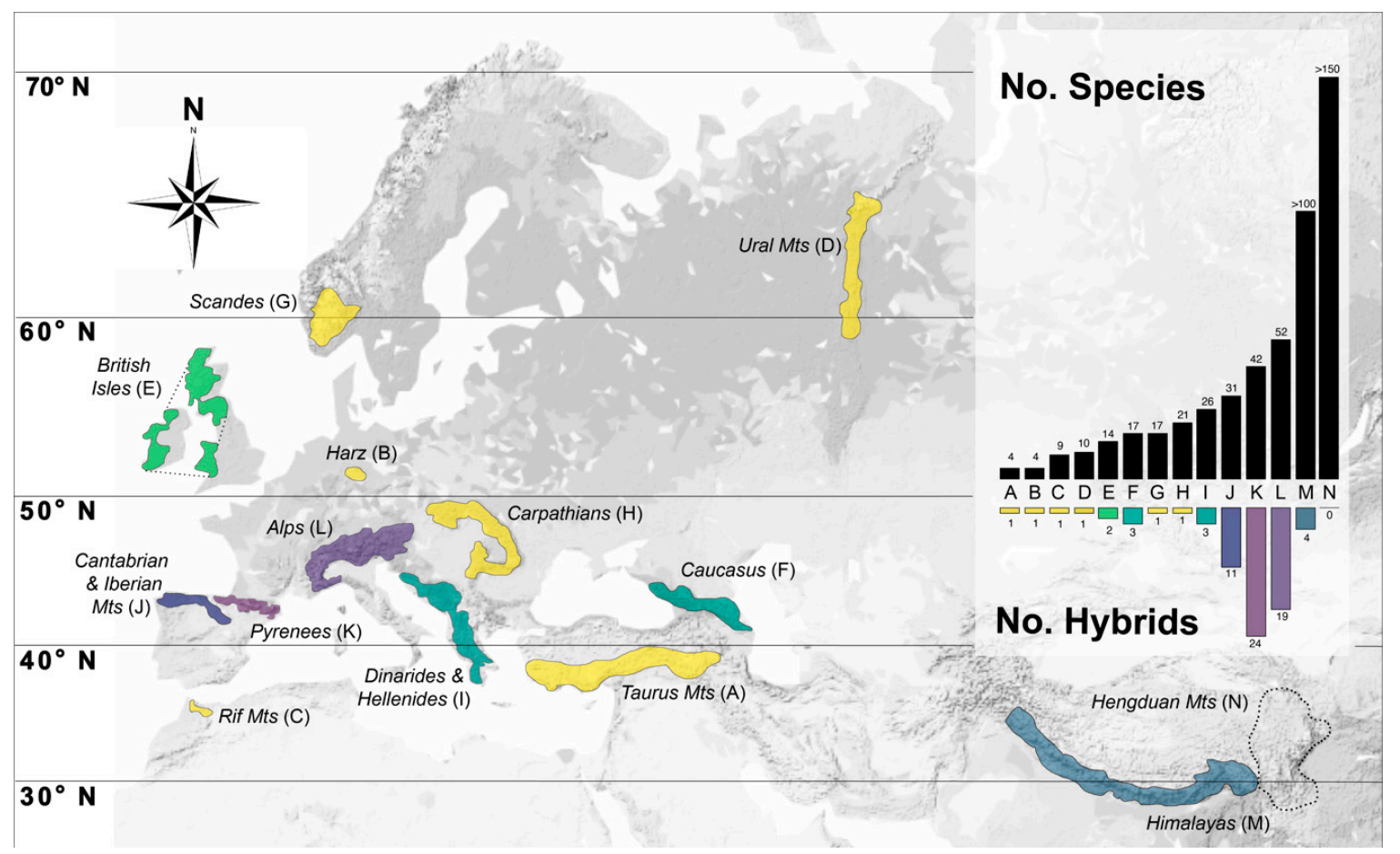

Figure 3. Hotspots of recent and/or ongoing hybridisation in Saxifraga in 14 mostly mountainous geographical regions: coloured areas represent approximate distribution of hybrid zones, and colours represent the number of recorded hybridising species pairs. The bar chart shows the approximate number of species in each of these regions based on the Global Biodiversity Information Facility (GBIF.org; DOIs of individual occurrence data download URLs are listed in Table S2). One hybridisation event from Siberia is not depicted because the available locality information was not accurate enough. The distribution of established hybrid species is not included, as it is uncertain where these species originated. This map is based on Google Maps Terrain Map (https://maps.googleapis.com/maps) created using the ggmap package [52] in R [53].

Surprisingly, hybridisation appears to be relatively rare in the mountains of Asia which house two fast-evolving clades, taxonomically treated as section Ciliatae subsection Hirculoideae and section Porphyrion subsection Kabschia (Engl.) Rouy and Camus [44]. Despite thorough morphological work [39,41,45], no reliable reports of hybridisation or introgression exist for Ciliatae, the largest Saxifraga section, which has its centre of diversity in the Tibeto-Himalayan region. We could only find two circumstantial accounts of potential gene flow between species of this section. First, higher 
than expected heterozygosity in microsatellite loci could be due to gene flow between S. egregia Engl. (subsection Hirculoideae) and a close relative such as S. diversifolia Wall. ex Ser. [54]. Second, triploid individuals discovered in four otherwise diploid Ciliatae species were suggested to be hybrids [55]; however, this has not yet been tested using molecular genetic methods and it remains unclear whether intra- or interspecific hybridisation was involved. In contrast, little to no evidence for hybridisation was found in Ciliatae subsection Rosulares using molecular methods [56]. Thus, hybridisation in the large section Ciliatae and its distribution across its subsections clearly need to be assessed more thoroughly, particularly as populations from distinct species can occur in close proximity of each other $(<10 \mathrm{~cm}$ [57]). In section Porphyrion, which is also species-rich in Asian mountain systems, only four species pairs were reported to hybridise in the Himalayas [58] and only three species pairs are known to hybridise in the Caucasus Mountains [45]. Several additional species pairs were suggested to hybridise on account of herbarium specimen studies [59], but this has not been confirmed so far. Hence, based on our literature review, hybridisation in Saxifraga seems to overwhelmingly occur in Europe, whereas it appears to be almost absent from or not documented in other parts of the world.

As might be expected, hybridisation events most frequently occur among species which have diverged within the last few million years [6]. Hybridisation is usually encountered within sections, subsections, and series, for example, between members of the section Mesogyne with crown age ca. $7 \mathrm{Ma}$ (Figure 1). However, some distantly related species or species which have diverged more anciently have also been shown to hybridise or to have hybridised. For example, in section Saxifraga, the likely progenitors of the hybrid species $S$. wahlenbergii belong to separate subsections (subsections Tridactylites (Haw.) Gornall and Androsaceae (Engl. and Irmsch.) Tkach, Röser and M.H.Hoffm.), which diverged at least $20 \mathrm{Ma}$ (Figure 1) [50]. However, hybridisation is difficult to date precisely and may have occurred anytime during the evolution of these lineages.

Historically, presumed hybridisation between more distantly related Saxifraga species, for example, between S. paniculata (section Ligulatae) and S. hirsuta L. or S. cuneifolia L. (both section Gymnopera) [47] (Figure 1), has sparked particular interest to several authors. These observations are particularly striking as several of these intersectional crosses were reported between non-sister groups, which have diverged relatively anciently (e.g., sections Ligulatae and Gymnopera estimated to have diverged ca. $19 \mathrm{Ma}$ [51]). However, according to the most recent molecular phylogenetic reconstruction of Saxifraga [42], intersectional hybridisation may not be as common in the genus as previously thought. For example, the hybridising species pairs S. mutata L. and S. aizoides L. as well as S. squarrosa Sieber and S. caesia L. [47] are now all considered to belong to the same section (Porphyrion), albeit to different subsections, and thus no longer constitute intersectional crosses. In addition, several older reports of intersectional hybrids, for example, between sections Saxifraga and Porphyrion, or Saxifraga and Trachyphyllum, still await confirmation and are currently considered unreliable [45,47]. This challenges the view of the perceived ease with which Saxifraga species are able to hybridise with rather distantly related congeners. Reliable accounts of intersectional hybrids seem to be restricted to crosses between sections Ligulatae and Gymnopera (Table S1). This observation is mirrored in topological incongruence and/or lack of node support with regard to these sections in plastid and nuclear DNA phylogenetic trees, which was previously hypothesised to be the result of ancient hybridisation and chloroplast capture $[42,60]$.

In contrast, some closely related and broadly co-occurring species seem to be unable to hybridise, e.g., S. aspera L. and S. bryoides L. [47,61], which belong to section Trachyphyllum and have diverged only 2.5 Ma (Figure 1). This pattern in section Trachyphyllum clearly deviates from that of its closest relatives, sections Ligulatae and Gymnopera. Thus, whereas young and sympatric Saxifraga species appear to be predisposed to hybridising, this is far from being the rule for the genus.

\section{Contemporary Hybrid Zones and Reproductive Isolation}

The numerous reports of contemporary hybridisation in Saxifraga $(n=73)$ are almost exclusively based on morphological observations of wild populations displaying intermediate phenotypes of 
two nominal species. In fact, these kinds of hybrid accounts are so common in Saxifraga that some authors have suggested that the identification and publication of intermediate hybrid populations had become almost like "a sport" at one point in time [47]. The sheer number of these reports clearly supports that natural hybridisation is a widespread phenomenon among Saxifraga species that live at least in partial sympatry, although parental species may no longer co-occur when their hybrids are found. These recent hybrids are usually short-lived [47], likely because their distribution is frequently narrowly restricted and reproductive barriers often seem to be in place to preserve the genetic integrity of parental species in the face of hybridisation.

Reproductive barriers may be either pre- or postzygotic and may act alone or sequentially. Both types contribute to varying degrees to reproductive isolation and, thus, preserve the uniqueness of the gene pool of each species [8,10,62-65]. In Saxifraga, several distinct reproductive barriers have been detected in some infrageneric groups, with low $\mathrm{F}_{1}$ fertility, an intrinsic postzygotic barrier, being one of the most commonly identified. $F_{1}$ hybrid sterility was repeatedly reported to play a major role in populations of interspecific hybrids in some subsections of the section Saxifraga [66-68]. In addition to complete $F_{1}$ hybrid sterility, several instances of reduced $F_{1}$ hybrid fertility have been reported for some intraspecific Saxifraga hybrids. For example, in S. hyperborea (section Mesogyne), hybrids between populations from different arctic regions had drastically reduced pollen fertility and seed fertility [69], suggesting that divergent and locally adapted populations of the same species may not be interfertile. Interestingly, reduced $F_{1}$ fertility and sterility appear to be mediated through different mechanisms. These include reduced male fertility, in particular, due to the triploid block (for section Ciliatae, see [55]; for section Mesogyne, see [70,71]; and for section Saxifraga, see [72]), low seed set [73] you jump the ref 73 seed sterility (for section Saxifraga subsections Saxifraga, Androsaceae and formerly recognised subsection Triplinervium, see $[67,68,74]$ ) or a combination thereof (for section Mesogyne, see [69]). These properties seem to be widespread among Saxifraga hybrids, as pollen from hybrid herbarium specimens is often inviable and seeds are rarely included in original hybrid descriptions [47]. This pattern is similar to that of other plant systems, in which reduced $\mathrm{F}_{1}$ fertility has commonly been established; examples include reduced seed set and pollen viability in Helianthus annuus L. and H. petiolaris Nutt. [75], reduced fruit and seed set in Castilleja minata Douglas and C. rhexifolia Rydb. [76], and reduced seed viability in Antirrhinum valentinum Font Quer [77].

Although $\mathrm{F}_{1}$ hybrid sterility occurs in distant corners of Saxifraga's evolution, it appears to be neither ubiquitous nor fully effective. For example, intraspecific hybrids of the section Saxifraga subsection Saxifraga (series Ceratophyllae (Haw.) S. Pawł.) produced predominantly weak, nonviable $F_{1}$ [78]. This suggests low $F_{1}$ viability or hybrid fitness, another commonly detected isolating mechanism [79], as the main barrier to gene flow. Importantly, some of these crosses did survive the $F_{1}$ stage and were able to produce viable $F_{2}$ offspring, suggesting that these kinds of crosses have the potential to give rise to long-lived lineages. Similar results were reported for artificial crosses between S. adscendens L. and S. tridactylites L. (section Saxifraga subsection Tridactylites), which showed low fertility but were able to give rise to few $F_{3}$ individuals under favourable greenhouse conditions [80]. This is reflective of a general pattern of postzygotic isolating barriers rarely causing complete reproductive isolation [9]. The reproductive success of such hybrids may be strongly environmentally mediated (extrinsic postzygotic barrier [65]). Such is the case for hybrids between Silene latifolia Poir. and S. dioica (L.) Clairv., which produce a normal seed set under benign conditions but have drastically reduced reproductive success under stressful conditions [81]. A similar pattern was observed for Saxifraga $\times$ alpigena Harry Sm. hybrids (section Porphyrion), which showed more or less uniform, morphologically intermediate populations in several localities, characterised by low seed set and/or sterile seeds [58]. However, one of the surveyed populations exhibited the characteristics of a hybrid swarm, suggesting that localised environmental conditions such as environmental stability, microclimate or habitat heterogeneity could affect the long-term outcome of hybridisation. This also underlines the need for a comprehensive population sampling for studies tackling hybrid species not always prioritised in the past (e.g., [73]). 
As evident from $S . \times$ alpigena, some Saxifraga hybrids seem to be subject only to weak fertility limitations or none at all. This allows the formation of hybrid swarms that are characterised by a morphological spectrum between the parental species, indicative of backcrossing afforded by interfertility. This seems to be a comparatively rare outcome of hybridisation in Saxifraga, with only 12 out of 73 contemporarily hybridising species pairs exhibiting this pattern, mainly in sections Porphyrion (5 out of 16 hybridising species reported to form hybrid swarms) and Gymnopera (2/2). However, some occasional hybrid swarms have also been reported for sections Mesogyne (1/2), Ligulatae (1/8) and Saxifraga subsection Saxifraga (3/40).

Hybrid swarms and parental backcrossing are of particular interest for the evolutionary implication of hybridisation. Introgression from or into the parental gene pools can result in long-term genomic consequences, including the transfer of favourable alleles (adaptive introgression [23]) or the eventual breakdown of genetic correlations (linkage groups [35]). This process has been observed in southwest Ireland, where introgressive hybridisation between $S$. hirsuta and $S$. spathularis is so common that pure populations of S. hirsuta are becoming rare [82]. This observation was confirmed by a recent study revealing density-dependent, asymmetric introgression into $S$. hirsuta [83]. Gene flow and introgression are often asymmetric because reproductive barriers frequently act asymmetrically (as for example, pollen competition in Silene [84]). In Saxifraga, this is exemplified by differential reproductive success (seed set and germination rate) of S. biflora All. $\times$ S. oppositifolia hybrids (section Porphyrion) depending on the maternal parent [73] as well as by observations of unidirectional introgression, for example, from S. cochlearis Rchb. into S. callosa Sm. ex Dicks. (section Ligulatae [85]) and from S. sibirica L. to S. cernua L. at their contact zone in the Ural Mountains (section Mesogyne [86]). These few cases are particularly important when investigating the role of hybridisation for the diversification of Saxifraga diversification. Introgression, in particular when it is adaptive, can be a major driving force in population differentiation, speciation and biodiversity $[6,87]$. This is seen, for example, in monkeyflowers (Mimulus L. [88]) and European white oaks (Quercus L. section Quercus [89]), and hybrid swarms have been suggested play an important role in originating adaptive radiation [7].

Unidirectional backcrossing and introgression, albeit at low levels, were also demonstrated for Saxifraga $\times$ hausmannii Kerner and its parental species, S. aizoides and S. mutata (section Porphyrion [90]). In this case, additional prezygotic reproductive barriers including phenological isolation and ecological isolation were shown to play an important role in counteracting the gene flow. It has thus become clear that the hybridising species of distinct infrageneric groups of Saxifraga are subject to a wide range of reproductive barriers and mechanisms counteracting gene flow. However, many questions remain regarding the role of these mechanisms in Saxifraga's evolutionary history. For example, although several barriers may act in concert and thus increase the strength of reproductive isolation $[9,91]$, studies investigating the gene flow among and within Saxifraga species usually concentrate on single mechanisms (e.g., [66,72,73,76,78]). Additionally, only a handful of studies have tackled gene flow and hybridisation on a genetic level (e.g., $[48,50,68,70]$ ), and genomic analyses are yet to be conducted. The roles of introgression and adaptive introgression are therefore far from being fully explained in Saxifraga.

\section{Hybrid Speciation}

In addition to numerous reports of recent or ongoing hybrid zones (Figure 3), ancient hybridisation has also given rise to at least 11 established Saxifraga species [50,67,71,92-94], either via autopolyploid; allopolyploid; or more rarely, homoploid speciation. Hybrid speciation events involving polyploidisation are common in Saxifraga, with a total of seven recognised allopolyploid or autopolyploid hybrid species. This is in line with findings regarding the role of polyploidy in the overall diversification of plants. A large proportion of angiosperm species are recent polyploids (ca. $35 \%$ ), and polyploidisation played a substantial role in the process of speciation for $15 \%$ of them [95]. The process of speciation via polyploidisation is not only relatively frequent but also rapid, as it confers almost instantaneous reproductive isolation [22]. For example, it appears that some allopolyploid 
species may be just a few hundred years old in Mimulus [96] and Cardamine [97]. In Saxifraga, examples of allopolyploid speciation include $S$. nathorstii Hayek $(2 n=52)$, a cross between $S$. aizoides and S. oppositifolia (both $2 n=26$, section Porphyrion), and S. osloensis $(2 n=44)$, via a hybridisation between S. adscendens and S. tridactylites (both $2 n=22$, section Saxifraga).

Similarly, autopolyploid speciation has demonstrably contributed to the diversification of some parts of the genus, for example, in S. cernua of section Mesogyne (tetraploid), which most likely is the result of an autopolyploid crossing event in S. sibirica (diploid [98]). Also, two independent rounds of autopolyploidisation, associated with ecological differentiation, likely were involved in the formation of the Madeiran Saxifraga taxa [67]. In addition to these speciation events, autopolyploidy has probably also been involved in the generation of species and populations with mixed ploidy levels as in S. moschata D.Don [67]. Species and populations displaying varying ploidy levels are abundant in Saxifraga, particularly in sections Ciliatae, Saxifraga, Mesogyne, Bronchiales and Irregulares (Figures 2 and 4). Although varying intraspecific ploidy levels are not necessarily associated with phenotypic differentiation [55], morphological and ecological differentiation between diploids and autopolyploids may occur in some cases [67]. This is particularly striking in the tetraploid individuals of S. oppositifolia (section Porphyrion), which have a narrower ecological niche than the diploid individuals and are characterised by varied growth forms including cushions [99]. Importantly, population structure was strongly driven by ploidy level rather than by geographical distance and only low amounts of gene flow were detected between diploid and tetraploid individuals, despite their co-occurrence in the same populations [100], suggesting that individuals of varying ploidy levels might be on a trajectory towards speciation.

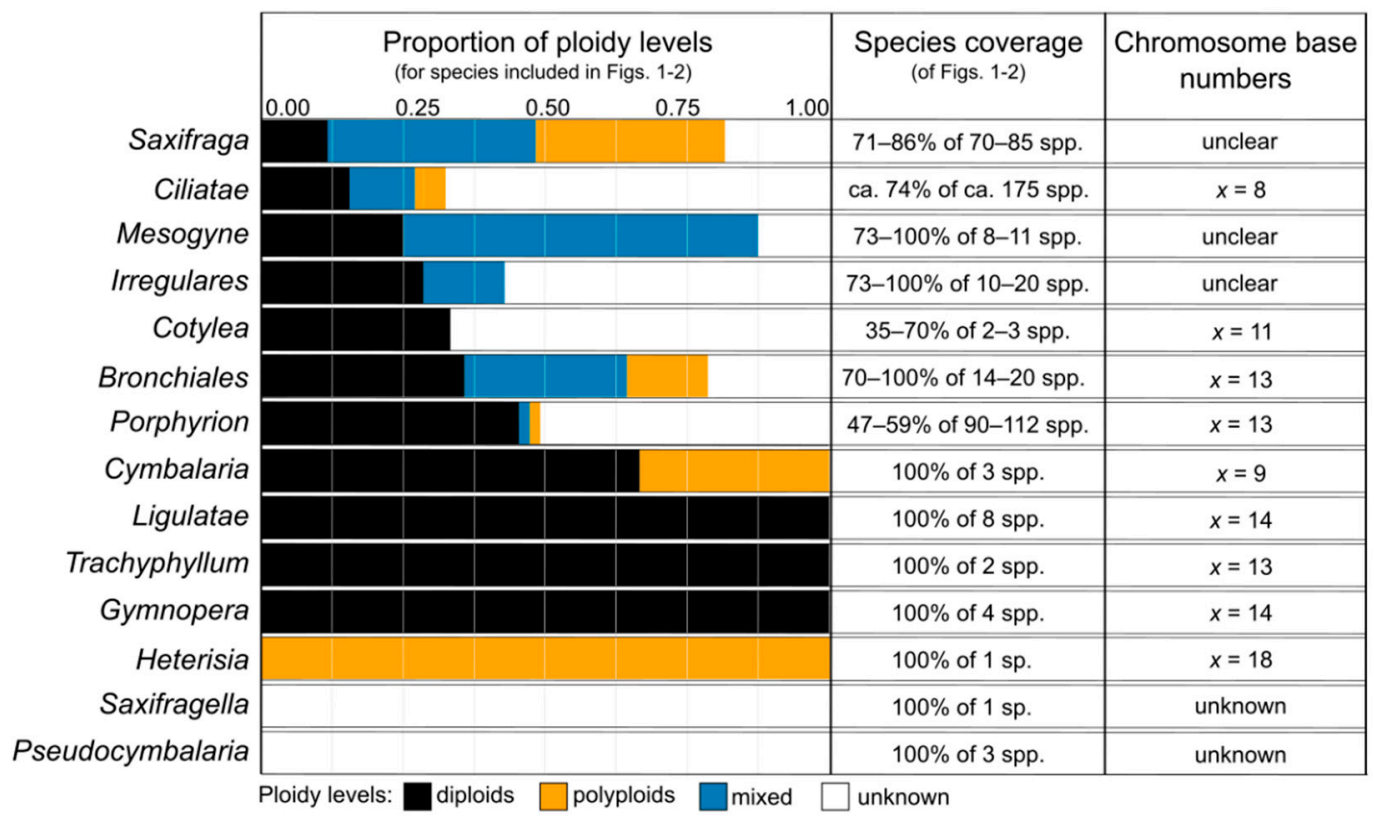

Figure 4. Ploidy levels within sections of Saxifraga, based upon the species included in our phylogenetic tree (see Figures 1 and 2; ca. 66\% of accepted species): bars show the proportion of diploid (black) and polyploid (orange) species as well as species with unknown (white) or mixed (blue) ploidy levels. Information on species coverage refers to the percentage of species included in our study (Figures 1 and 2) with regards to the accepted number of species per section. Ranges are provided whenever the total number of species is still debated. Likely, chromosome base numbers were inferred from available chromosome number data (Table S3).

Homoploid hybrid speciation is also hypothesised for some taxa of the section Saxifraga (formerly recognised subsection Triplinervium) [67]. However, if a narrow view of homoploid hybrid speciation is adopted (e.g., see [24]), additional analyses on the S. moschata species complex are needed 
to confirm whether hybrid speciation did in fact occur in homoploidy. Nonetheless, since uneven ploidy levels (e.g., triploidy) generally bring about sterility, parental backcrossing and hybrid swarms as described above are likely indicative of hybridisation in homoploidy. Thus, even though hybrid swarms generally point to current hybrid zones, it is likely that this process might also have been involved in past speciation events in Saxifraga. In general, homoploid hybrid speciation, although considered much less common than allopolyploid speciation, is increasingly acknowledged as a mechanism of speciation [20] such as in several species of Helianthus [101,102] and Pinus L. [103,104].

\section{Phylogenetic and Geographic Distribution of Ploidy Levels}

As exemplified by S. oppositifolia and S. moschata, a comprehensive analysis of ploidy levels and chromosome numbers will likely be critical in furthering our understanding of the diversification among species and populations, including the ongoing processes. Saxifraga is notorious for its cytological complexity including aneuploidy, dysploidy, occurrence of supernumerary chromosomes, homoploidy, and large differences in chromosome sizes among closely related species $[44,66,67,105]$. In addition, the genus displays a remarkable diversity in terms of chromosome numbers (e.g., chromosome base numbers $x=8,9,11,13,14$ and 18 depending on the section), large infrageneric chromosome number variation (Table S3) and ploidy levels, even within sections and among closely related species. However, our knowledge of chromosome numbers and the relative frequency of diploid vs. polyploid (or mixed ploidy species) varies strongly across the genus (Figure 4). Here, we will only report on ploidy levels of species present in our phylogenetic tree ( $n=296$, ca. $66 \%$ of known species diversity), of which sampling was designed to optimise the morphological, taxonomic and geographic coverage of the genus [51].

The relative frequency of known ploidy levels varies strongly among sections (Figure 4). Overall, ploidy levels are only known for about half of the species in our tree, and information is disproportionately more complete for the European than for the Asian sections. For example, the European section Saxifraga (sampled $n=59$ ) only includes ca. $18 \%$ of species of unknown ploidy level, whereas $72 \%$ of species in the Asian section Ciliatae $(n=130)$ lack any information on their chromosome number or ploidy level. With ca. 51\% species of unknown ploidy level, section Porphyrion $(n=53)$ appears intermediate, although information is particularly scant in the Asian representatives of the section, such as in subsection Kabschia. This lack of available data for the Tibeto-Himalayan region makes it difficult to assess the role of polyploidisation for diversification in this region or to compare the speciation processes in distant mountain regions or between infrageneric taxonomic groups.

Despite a high proportion of missing data (no ploidy information available for 140 of 296 taxa in our tree, $47.3 \%)$, some patterns still emerge when ploidy levels are plotted onto the phylogeny of Saxifraga (Figures 1 and 2). Sections show varying proportions of exclusively diploid versus polyploid species, including those of variable ploidy. This is particularly interesting when combined with our results regarding hybridisation. For example, the section Saxifraga, which contains the highest number of hybridising species pairs, is dominated by poly- or mixoploid species $(69.5 \%)$. In contrast, Porphyrion, Saxifraga's second largest section with likewise widespread hybridisation (see above), contains only three species identified as polyploids in our sampling. Thus, diversification is not necessarily associated with polyploidy in this section. The sections Trachyphyllum, Gymnopera and Ligulatae, all closely related to Porphyrion, are also made up exclusively of diploids, despite displaying high to moderate degrees of hybridisation (except for section Trachyphyllum). This suggests that these groups are generally not especially prone to auto- or allopolyploidisation. Other sections, such as Bronchiales and Mesogyne, exhibit a different pattern with higher proportions of polyploid and mixed ploidy species, respectively, suggesting a greater role of polyploidisation in their evolutionary history. Indeed, the circumpolar species S. rivularis L. $[93,106,107]$ and S. cernua [86] of the section Mesogyne show extremely complex reticulate evolution involving allopolyploidisation and interspecific gene flow, a pattern commonly observed in arctic taxa [30]. These processes could therefore have also been relevant to the evolution of other arctic Saxifraga species, for example, of the sections Bronchiales and Pseudocymbalaria. 
Mixed ploidy levels can be indicative of inter- or intraspecific hybridisation. For example, all known hybridising species of the section Mesogyne display varying ploidy levels (Figures 1 and 4) but not all species displaying mixed ploidy levels are known to hybridise. The extent of species having mixed ploidy levels might therefore give us a better idea of gene flow in this section, even though we cannot yet distinguish between intraspecific and interspecific events. This reasoning could also be helpful for the section Ciliatae, for which very few chromosome counts and ploidy assessments are available. Out of a total of 43 species for which we could find information, seven were polyploid and 15 had mixed ploidy levels. This suggests that polyploidisation, associated with either intra- or interspecific gene flow, was likely an important process in the diversification of this section. However, the available cytological data are not sufficient to conclusively understand the role of polyploidy for the accelerated diversification observed in section Ciliatae subsection Hirculoideae [44].

\section{Hybridisation and Polyploidisation as Drivers for Saxifraga Diversity}

Our review of hybridisation and genome ploidy within Saxifraga shows that some extent of interspecific gene flow may have been an evolutionary companion of saxifrages for at least several million years. The distinct sections of this large genus vary widely in both their propensity to hybridise and the state of research on this subject. In particular, the three largest sections of Saxifraga, namely Ciliatae, Porphyrion and Saxifraga, show widely contrasting patterns concerning the proportion of hybridising species, polyploidy and fates of their hybrids. Ultimately, this suggests that hybridisation and polyploidisation have played varying roles during diversification of the genus.

Section Saxifraga is certainly the best-studied section concerning hybridisation and cytology. This is likely due to its high proportion of hybridising species and its distribution in the major European mountain ranges, a combination which has led to a longstanding interest in the species of this section among European botanists. The large amount of empirical evidence reveals that many of the currently hybridising species pairs of this section are subject to postzygotic isolating barriers, which often lead to short-lived hybrid populations. However, extreme cytological complexity is observed in this section, including aneuploidy and dysploidy. Along with widespread topological incongruences produced by nuclear and plastid DNA data in the phylogenetic reconstructions [42], this complexity is suggestive of interspecific gene flow that produced long-term genomic signatures [108]. Largely overlapping distribution ranges in the Alps and the Pyrenees as well as incomplete reproductive isolation have likely enabled extensive hybridisation and polyploidisation, which appear to have contributed to the diversity in this section. Furthermore, this section exhibits a high degree of tolerance to chromosomal changes such as centric fusion or fission, which has likely further contributed to speciation [66,67]. Previous analyses, however, did not reveal increased diversification rates in this section [43], suggesting that the processes contributing to species differentiation were acting sequentially and not necessarily rapidly.

In contrast, the sections Ciliatae and Porphyrion exhibited accelerated diversification compared to the remainder of the genus [43]. Our review showed that hybridisation is a common process in natural populations of the section Porphyrion and that reproductive barriers seem to be ineffective at preventing backcrossing and introgression, often leading to hybrid swarms. This circumstance is also mirrored in the sheer number of artificial crosses ( $>100$ [45]). At the same time, polyploidisation was likely not the rule in this section, which could have contributed to the apparent ease of hybrid swarm formation through the avoidance of uneven ploidy levels. Since hybrid swarms are assumed to be at the basis of rapid, adaptive radiations [7], this observation is particularly striking as it strengthens the view that rapid radiation in this group might have been adaptive, i.e., associated with significant eco-morphological differentiation and colonisation of novel adaptive niches. The rapid diversification in this section, especially in the subsection Kabschia, was shown to have been associated to the evolution of two key traits ("key innovations"), the cushion-habit and lime-secreting hydathodes, which facilitated the colonisation of new adaptive zones [43]. Taken together, these results could indicate a role of adaptive processes in the diversification of this group. However, differentiating the adaptive and the nonadaptive radiations is not trivial, since eco-morphological differentiation 
can by cryptic or relate to nonobvious niche differentiation. Thus, even though hybridisation was not confined to the rapidly diversifying subsection Kabschia, it is very probable that interspecific gene flow contributed to accelerated adaptive diversification in this section. This has likely played an additional role in shaping the diversity of the section Porphyrion. Finally, although the section Ciliatae is insufficiently investigated, the available evidence indicates that auto- and possibly allopolyploidy likely contributed to diversification. Still, we cannot draw any inferences on the relative contribution of this process compared to other scenarios, such as rapid allopatric speciation driven by habitat heterogeneity, soil properties and/or changing climatic conditions, as recently proposed [57], to overall species richness in this section. We had originally hoped to use the results of this review to deepen our understanding of the section Ciliatae. However, hybridisation and introgression are also not well-studied in its closest sister sections, Bronchiales and Pseudocymbalaria. Due to the large variation in frequency and outcome of interspecific hybridisation displayed by the rest of the genus, extrapolation of any of these insights to this section is impossible.

\section{Perspectives in the Context of Mountain Biodiversity}

Mountain systems have experienced varying degrees of glaciation and differ greatly in their overlap between present-day and last glacial maximum temperature profiles [109]. These differences are likely to have affected in situ diversification, including processes such as hybridisation and polyploidisation [32]. In theory, the observed differences in diversity, hybridisation and frequency of polyploids within Saxifraga (for instance, among sections Saxifraga and Porphyrion) would therefore be highly suited to investigate the effect of the geographic context and differences among mountain systems, such as altitudinal ranges, habitat heterogeneity, and historical processes such as uplift or glaciation history. This requires a more detailed assessment of mountain attributes such as analysing the Himalayas, the Qinghai-Tibet Plateau and the Hengduan Mountains individually instead of as one contiguous mountainous region, as is often done. First and foremost, however, more comprehensive knowledge of ploidy levels, chromosome numbers and incidence of hybridisation as well as the mechanisms of reproductive isolation and their genomic basis is direly needed to assemble the full picture of their role in the diversification of Saxifraga, particularly of the Asian species. In addition, population genomics analyses and population ecological investigations will be required to fully unravel the intricacies of these processes in the distinct sections and regions of Saxifraga's distribution and to compare their role to that in other arctic-alpine groups.

Supplementary Materials: The following are available online at http://www.mdpi.com/1424-2818/12/11/440/s1, Table S1: Saxifraga hybrids included in this study and their geographic distribution, Table S2: List of GBIF occurrence download DOI URLs used to create Figure 3, Table S3: Chromosome number reports for taxa of Saxifraga used in this study.

Author Contributions: J.E. initiated the project and obtained the support of other authors to design it. All authors were involved with the review process. The manuscript and figures were elaborated by J.E. and A.F. with the support of N.T. All authors contributed to the final version of the manuscript. All authors have read and agreed to the published version of the manuscript.

Funding: This research received no external funding.

Acknowledgments: Financial support for this study was provided by the German Science Foundation (Deutsche Forschungsgemeinschaft), project no. FA1117/1-2 to AF. We further acknowledge the financial support of the Open Access Publication Fund of the Martin Luther University Halle-Wittenberg. In addition, we thank four anonymous reviewers for their constructive feedback and are grateful to Joanne Ashnest for proofreading and language editing.

Conflicts of Interest: The authors declare no conflict of interest.

\section{References}

1. Barton, N.H.; Hewitt, G.M. Analysis of hybrid zones. Annual Rev. Ecol. Evol. Syst. 1985, 16, 113-148. [CrossRef]

2. Arnold, M.L. Natural Hybridization and Evolution; Oxford University Press: New York, NY, USA, 1997. 
3. Wagner, W.H. Biosystematics and evolutionary noise. Taxon 1970, 19, 146-151.

4. Stebbins, G.L. Variation and Evolution in Plants; Columbia University Press: New York, NY, USA, 1950.

5. Stebbins, G.L. The role of hybridization in evolution. Proc. Am. Philos. Soc. 1959, 103, 231-251.

6. Abbott, R.; Albach, D.; Ansell, S.; Arntzen, J.W.; Baird, S.J.E.; Bierne, N.; Boughman, J.; Brelsford, A.; Buerkle, C.A.; Buggs, R.; et al. Hybridization and speciation. J. Evol. Biol. 2013, 26, 229-246. [CrossRef] [PubMed]

7. Seehausen, O. Hybridization and adaptive radiation. Trends Ecol. Evol. 2004, 19, 198-207. [CrossRef]

8. Coyne, J.A.; Orr, H.A. Speciation; Oxford University Press: Sunderland, MA, USA, 2004.

9. Lowry, D.B.; Modliszewski, J.L.; Wright, K.M.; Wu, C.A.; Willis, J.H. The strength and genetic basis of reproductive isolating barriers in flowering plants. Philos. Trans. Ser. B 2008, 363, 3009-3021. [CrossRef]

10. Nosil, P.; Vines, T.H.; Funk, D.J. Reproductive isolation caused by natural selection against immigrants from divergent habitats. Evolution 2005, 59, 705-719. [CrossRef]

11. Sobel, J.M.; Chen, G.F.; Watt, L.R.; Schemske, D.W. The biology of speciation. Evolution 2010, 64, $295-315$. [CrossRef]

12. Mallet, J. Hybrid speciation. Nature 2007, 446, 279-283. [CrossRef]

13. Rieseberg, L.H. Hybrid origin of plant species. Annual Rev. Ecol. Evol. Syst. 1997, 28, 359-389. [CrossRef]

14. Mallet, J. Hybridization as an invasion of the genome. Trends Ecol. Evol. 2005, 20, 229-237. [CrossRef] [PubMed]

15. Payseur, B.A.; Rieseberg, L.H. A genomic perspective on hybridization and speciation. Mol. Ecol. 2016, 25, 2337-2360. [CrossRef] [PubMed]

16. Nieto Feliner, G.; Casacuberta, J.; Wendel, J.F. Genomics of evolutionary novelty in hybrids and polyploids. Front. Genet. 2020, 11, 792. [CrossRef] [PubMed]

17. Tkach, N.; Schneider, J.; Döring, E.; Wölk, A.; Hochbach, A.; Nissen, J.; Winterfeld, G.; Meyer, S.; Gabriel, J.; Hoffmann, M.H.; et al. Phylogenetic lineages and the role of hybridization as driving force of evolution in grass supertribe Poodae. Taxon 2020, 69, 234-277. [CrossRef]

18. Lexer, C.; Welch, M.E.; Raymond, O.; Rieseberg, L.H. The origin of ecological divergence in Helianthus paradoxus (Asteraceae): Selection on transgressive characters in a novel hybrid habitat. Evolution 2003, 57, 1989-2000. [CrossRef]

19. Gross, B.L.; Rieseberg, L.H. The ecological genetics of homoploid hybrid speciation. Heredity 2005, 96, 241-252. [CrossRef]

20. Yakimowski, S.B.; Rieseberg, L.H. The role of homoploid hybridization in evolution: A century of studies synthesizing genetics and ecology. Am. J. Bot. 2014, 101, 1247-1258. [CrossRef]

21. Rieseberg, L.H.; Raymond, O.; Rosenthal, D.M.; Lai, Z.; Livingstone, K.; Nakazato, T.; Durphy, J.L.; Schwarzbach, A.E.; Donovan, L.A.; Lexer, C. Major ecological transitions in wild sunflowers facilitated by hybridization. Science 2003, 301, 1211-1216. [CrossRef]

22. Soltis, P.S.; Soltis, D.E. The role of hybridization in plant speciation. Annu. Rev. Plant Biol. 2009, 60, 561-588. [CrossRef]

23. Abbott, R.J.; Hegarty, M.J.; Hiscock, S.J.; Brennan, A.C. Homoploid hybrid speciation. Taxon 2010, 59, 1375-1386.

24. Schumer, M.; Rosenthal, G.G.; Andolfatto, P. How common is homoploid hybrid speciation? Evolution 2014, 68, 1553-1560. [CrossRef] [PubMed]

25. Nieto Feliner, G.; Álvarez, I.; Fuertes-Aguilar, J.; Heuertz, M.; Marques, I.; Moharrek, F.; Piñeiro, R.; Riina, R.; Rosselló, J.A.; Soltis, P.S.; et al. Is homoploid hybrid speciation that rare? An empiricist's view. Heredity 2017, 118, 513-516. [CrossRef] [PubMed]

26. Karrenberg, S.; Favre, A. Genetic and ecological differentiation in the hybridizing campions Silene dioica and S. latifolia. Evolution 2008, 62, 763-773. [CrossRef] [PubMed]

27. Lamont, B.B.; He, T.; Enright, N.J.; Krauss, S.L.; Miller, B.P. Anthropogenic disturbance promotes hybridization between Banksia species by altering their biology. J. Evol. Biol. 2003, 16, 551-557. [CrossRef]

28. Cruzan, M.B.; Arnold, M.L. Ecological and genetic associations in an Iris hybrid zone. Evolution 1993, 47, 1432-1445. [CrossRef]

29. Johnston, J.A.; Wesselingh, R.A.; Bouck, A.C.; Donovan, L.A.; Arnold, M.L. Intimately linked or hardly speaking? The relationship between genotype and environmental gradients in a Louisiana Iris hybrid population. Mol. Ecol. 2001, 10, 673-681. [CrossRef] 
30. Brochmann, C.; Brysting, A.K.; Alsos, I.G.; Grundt, H.H.; Scheen, A.-C.; Elven, R. Polyploidy in arctic plants. Biol. J. Linn. Soc. 2004, 82, 521-536. [CrossRef]

31. Stebbins, G.L. Polyploidy and the distribution of the arctic-alpine flora: New evidence and a new approach. Bot. Helv. 1984, 94, 1-13. [CrossRef]

32. Rice, A.; Šmarda, P.; Novosolov, M.; Drori, M.; Glick, L.; Sabath, N.; Meiri, S.; Belmaker, J.; Mayrose, I. The global biogeography of polyploid plants. Nat. Ecol. Evol. 2019, 3, 265-273. [CrossRef]

33. Löve, Á.; Löve, D. Arctic polyploidy. Proc. Genet. Soc. Canada 1957, 2, 23-27.

34. Tkach, N.V.; Hoffmann, M.H.; Röser, M.; Korobkov, A.A.; von Hagen, K.B. Parallel evolutionary patterns in multiple lineages of arctic Artemisia L. (Asteraceae). Evolution 2008, 62, 184-198. [CrossRef] [PubMed]

35. Seehausen, O. Conditions when hybridization might predispose populations for adaptive radiation. J. Evol. Biol. 2013, 26, 279-281. [CrossRef] [PubMed]

36. Landis, J.B.; Soltis, D.E.; Li, Z.; Marx, H.E.; Barker, M.S.; Tank, D.C.; Soltis, P.S. Impact of whole-genome duplication events on diversification rates in angiosperms. Am. J. Bot. 2018, 105, 348-363. [CrossRef] [PubMed]

37. Grant, P.R.; Grant, B.R. Hybridization increases population variation during adaptive radiation. Proc. Natl. Acad. Sci. USA 2019, 116, 23216-23224. [CrossRef]

38. Körner, C. Coldest places on earth with angiosperm plant life. Alpine Bot. 2011, 121, 11-22. [CrossRef]

39. Pan, J.; Gornall, R.J.; Ohba, H. Saxifraga L. In Flora of China, vol. 8, Brassicaceae through Saxifragaceae; Wu, C., Raven, P.H., Eds.; Science Press: Beijing, China; Missouri Botanical Garden Press: St. Louis, MO, USA, 2001; pp. 280-344.

40. Brouillet, L.; Elvander, P.E. Saxifraga L. In Flora of North America North of Mexico, vol. 8, Magnoliophyta: Paeoniaceae to Ericaceae; Flora of North America Editorial Committee, Ed.; Oxford University Press: New York, NY, USA; Oxford, UK, 2009; pp. 43-166.

41. Akiyama, S.; Gornall, R.J. Saxifraga L. In Flora of Nepal, vol. 3, Magnoliaceae to Rosaceae; Watson, M.F., Akiyama, S., Ikeda, H., Pendry, C.A., Rajbhandari, K.R., Shrestha, K.K., Eds.; Royal Botanic Garden Edinburgh: Edinburgh, UK, 2012; pp. 254-303.

42. Tkach, N.; Röser, M.; Miehe, G.; Muellner-Riehl, A.N.; Ebersbach, J.; Favre, A.; Hoffmann, M.H. Molecular phylogenetics, morphology and a revised classification of the complex genus Saxifraga (Saxifragaceae). Taxon 2015, 64, 1159-1187. [CrossRef]

43. Ebersbach, J.; Schnitzler, J.; Favre, A.; Muellner-Riehl, A.N. Evolutionary radiations in the species-rich mountain genus Saxifraga L. BMC Evol. Biol. 2017, 17, 1-13.

44. Ebersbach, J.; Muellner-Riehl, A.N.; Favre, A.; Paule, J.; Winterfeld, G.; Schnitzler, J. Driving forces behind evolutionary radiations: Saxifraga section Ciliatae (Saxifragaceae) in the region of the Qinghai-Tibet Plateau. Bot. J. Linn. Soc. 2018, 186, 304-320.

45. McGregor, M. Saxifrages. A Definitive Guide to the 2000 Species, Hybrids \& Cultivars; Timber Press: Portland, OR, USA, 2008.

46. McGregor, M.; Harding, W. Saxifrages: The Complete List of Species; The Saxifrage Society: Hutton, East Yorkshire, UK, 1998.

47. Webb, D.A.; Gornall, R.J. A Manual of Saxifrages and Their Cultivation, 1st ed.; Timber Press, Incorporated: Portland, OR, USA, 1989.

48. Brochmann, C.; Nilsson, T.; Gabrielson, T.M. A classic example of postglacial allopolyploid speciation re-examined using RAPD markers and nucleotide sequences: Saxifraga osloensis (Saxifragaceae). Symb. Bot. Upsal. 1996, 31, 75-89.

49. Nilsson, T.; Jorde, P.E. Allozyme variation in allotetraploid Saxifraga osloensis and its diploid progenitors. Nordic J. Bot. 1998, 18, 425-430.

50. Tkach, N.; Röser, M.; Suchan, T.; Cieślak, E.; Schönswetter, P.; Ronikier, M. Contrasting evolutionary origins of two mountain endemics: Saxifraga wahlenbergii (Western Carpathians) and S. styriaca (Eastern Alps). BMC Evol. Biol. 2019, 19, 18. [CrossRef]

51. Ebersbach, J.; Muellner-Riehl, A.N.; Michalak, I.; Tkach, N.; Hoffmann, M.H.; Röser, M.; Sun, H.; Favre, A. In and out of the Qinghai-Tibet Plateau: Divergence time estimation and historical biogeography of the large arctic-alpine genus Saxifraga L. J. Biogeogr. 2017, 44, 900-910. [CrossRef]

52. Kahle, D.; Wickham, H. ggmap: Spatial visualization with ggplot2. R J. 2013, 5, 144-161. 
53. R Core Team. R: A Language and Environment for Statistical Computing; R Foundation for Statistical Computing: Vienna, Austria, 2020.

54. Zhang, F.; Li, Y.; Gao, Q.; Lei, S.; Khan, G.; Yang, H.; Chen, S. Development and characterization of polymorphic microsatellite loci for Saxifraga egregia (Saxifragaceae). Appl. Plant. Sci. 2015, 3. [CrossRef]

55. Wakabayashi, M.; Ohba, H. Cytotaxonomic study of the Himalayan Saxifraga. In The Himalayan Plants; Ohba, H., Malla, S.B., Eds.; University Tokyo Press: Tokyo, Japan, 1988; pp. 71-90.

56. Gao, Q.-B.; Li, Y.; Gengji, Z.-M.; Gornall, R.J.; Wang, J.-L.; Liu, H.-R.; Jia, L.-K.; Chen, S.-L. Population genetic differentiation and taxonomy of three closely related species of Saxifraga (Saxifragaceae) from Southern Tibet and the Hengduan Mountains. Front. Plant. Sci. 2017, 8, 1325. [CrossRef] [PubMed]

57. Liu, L.; Xu, Y.; Tang, Y.; Du, W.; Shao, C.; Wu, J.; Zhao, L.; Zhang, L.; Liu, J.; Xu, X. The importance of including soil properties when disentangling the drivers of species richness: The case of the alpine genus Saxifraga L. in China. Front. Ecol. Evol. 2020, 8, 388. [CrossRef]

58. Bürgel, J. Hybridisation in Saxifraga subsection Kabschia (Saxifragaceae) from the Central Himalaya. Phyton 2007, 47, 191-204.

59. Smith, H. Saxifraga of the Himalaya: 1. Section Kabschia. Bull. Brit. Mus. (Nat. Hist.) Bot. 1958, 2, 83-129.

60. Conti, E.; Soltis, D.E.; Hardig, T.M.; Schneider, J. Phylogenetic relationships of the silver saxifrages (Saxifraga, sect. Ligulatae Haworth): Implications for the evolution of substrate specificity, life histories, and biogeography. Mol. Phylogenet. Evol. 1999, 13, 536-555.

61. DeChaine, E.G.; Anderson, S.A.; McNew, J.M.; Wendling, B.M. On the evolutionary and biogeographic history of Saxifraga sect. Trachyphyllum (Gaud.) Koch (Saxifragaceae Juss.). PLoS ONE 2013, 8, e69814. [CrossRef]

62. Kay, K.M. Reproductive isolation between two closely related hummingbird-pollinated Neotropical gingers. Evolution 2006, 60, 538-552. [CrossRef] [PubMed]

63. Ramsey, J.; Bradshaw, H.D., Jr.; Schemske, D.W. Components of reproductive isolation between the monkeyflowers Mimulus lewisii and M. cardinalis (Phrymaceae). Evolution 2003, 57, 1520-1534. [PubMed]

64. Schluter, D. Ecology and the origin of species. Trends Ecol. Evol. 2001, 16, 372-380. [CrossRef] [PubMed]

65. Seehausen, O.; Butlin, R.K.; Keller, I.; Wagner, C.E.; Boughman, J.W.; Hohenlohe, P.A.; Peichel, C.L.; Saetre, G.-P.; Bank, C.; Brännström, A.; et al. Genomics and the origin of species. Nat. Rev. Genet. 2014, 15, 176-192. [CrossRef] [PubMed]

66. Vargas, P.; Nieto Feliner, G. Cytotaxonomical study of Saxifraga sect. Ceratophyllae s.l. (Saxifragaceae). Plant. Syst. Evol. 1995, 197, 209-223.

67. Mas de Xaxars, G.; García-Fernández, A.; Barnola, P.; Martín, J.; Mercadé, A.; Vallès, J.; Vargas, P.; Vigo, J.; Garnatje, T. Phylogenetic and cytogenetic studies reveal hybrid speciation in Saxifraga subsect. Triplinervium (Saxifragaceae). J. Syst. Evol. 2015, 53, 53-62. [CrossRef]

68. García-Maroto, F.; Garrido-Cárdenas, J.A.; Gómez-Mercado, F.; Guil-Guerrero, J.; López Alonso, D. Natural hybridisation and phylogenetic position of Saxifraga trabutiana (Saxifragaceae) inferred from ISSR markers and ITS sequences. Ann. Bot. Fenn. 2003, 40, 5-13.

69. Gustafsson, A.L.S. Speciation in Arctic and Alpine Diploid Plants. Doctoral Thesis, University of Oslo, Oslo, Norway, 2013.

70. Dymshakova, O.S.; Semerikov, V.L.; Lascoux, M. AFLP analysis to estimate the genetic contribution of parents to progeny from hybridization between Saxifraga sibirica L. and S. cernua L. Russ. J. Ecol. 2012, 43, 347-351. [CrossRef]

71. Steen, S.W.; Gielly, L.; Taberlet, P.; Brochmann, C. Same parental species, but different taxa: Molecular evidence for hybrid origins of the rare endemics Saxifraga opdalensis and S. svalbardensis (Saxifragaceae). Bot. J. Linn. Soc. 2000, 132, 153-164.

72. Díaz González, T.E.; Fernández Areces, M.P.; Pérez Carro, J. Nuevos híbridos y otros datos biométricos del genero Saxifraga L., sección Dactyloides Tausch en el NW de la Península Ibérica. Anales Jard. Bol. Madrid. 1990, 47, 65-85.

73. Gugerli, F. Hybridization of Saxifraga oppositifolia and S. biflora (Saxifragaceae) in a mixed alpine population. Plant. Syst. Evol. 1997, 207, 255-272.

74. Köckinger, H. Saxifraga styriaca spec. nova (Saxifragaceae)—ein Endemit der östlichen Niederen Tauern (Steiermark, Österreich). Phyton 2003, 43, 79-108. 
75. Sambatti, J.B.M.; Strasburg, J.L.; Ortiz-Barrientos, D.; Baack, E.J.; Rieseberg, L.H. Reconciling extremely strong barriers with high levels of gene exchange in annual sunflowers. Evolution 2012, 66, 1459-1473. [CrossRef] [PubMed]

76. Hersch-Green, E.I. Polyploidy in Indian paintbrush (Castilleja; Orobanchaceae) species shapes but does not prevent gene flow across species boundaries. Am. J. Bot. 2012, 99, 1680-1690. [CrossRef]

77. Carrió, E.; Güemes, J. The effectiveness of pre- and post-zygotic barriers in avoiding hybridization between two snapdragons (Antirrhinum L.: Plantaginaceae). Bot. J. Linn. Soc. 2014, 176, 159-172. [CrossRef]

78. Vargas, P.; Nieto Feliner, G. Artificial hybridization within Saxifraga pentadactylis (Saxifragaceae). Nordic J. Bot. 1996, 16, 257-266. [CrossRef]

79. Baack, E.; Melo, M.C.; Rieseberg, L.H.; Ortiz-Barrientos, D. The origins of reproductive isolation in plants. New Phytol. 2015, 207, 968-984. [CrossRef]

80. von Drygalski, U. Über die Entstehung einer tetraploiden, genetisch ungleichmäßigen $\mathrm{F}_{2}$ aus der Kreuzung Saxifraga adscendens L. $\times$ Saxifraga tridactylites L. Z. Indukt. Abstammungs-Vererbungsl. 1935, 69, $278-300$. [CrossRef]

81. Favre, A.; Karrenberg, S. Stress tolerance in closely related species and their first-generation hybrids: A case study of Silene. J. Ecol. 2011, 99, 1415-1423. [CrossRef]

82. Webb, D.A. Hybridization and variation in the Robertsonian saxifrages. Proc. R. Ir. Acad. B 1950, 53, 85-97.

83. Beatty, G.E.; Barker, L.; Chen, P.-P.; Kelleher, C.T.; Provan, J. Cryptic introgression into the kidney saxifrage (Saxifraga hirsuta) from its more abundant sympatric congener Saxifraga spathularis, and the potential risk of genetic assimilation. Ann. Bot. 2015, 115, 179-186. [CrossRef] [PubMed]

84. Rahmé, J.; Widmer, A.; Karrenberg, S. Pollen competition as an asymmetric reproductive barrier between two closely related Silene species. J. Evol. Biol. 2009, 22, 1937-1943. [CrossRef] [PubMed]

85. Grassi, F.; Labra, M.; Minuto, L.; Casazza, G.; Sala, F. Natural hybridization in Saxifraga callosa Sm. PLoS Biol. 2006, 8, 243-252. [CrossRef]

86. Kapralov, M.V.; Gabrielsen, T.M.; Sarapultsev, I.E.; Brochmann, C. Genetic enrichment of the arctic clonal plant Saxifraga cernua at its southern periphery via the alpine sexual Saxifraga sibirica. Molec. Ecol. 2006, 15, 3401-3411. [CrossRef]

87. Suarez-Gonzalez, A.; Lexer, C.; Cronk, Q.C.B. Adaptive introgression: A plant perspective. Biol. Lett. 2018, 14. [CrossRef]

88. Stankowski, S.; Streisfeld, M.A. Introgressive hybridization facilitates adaptive divergence in a recent radiation of monkeyflowers. Proc. Biol. Sci. 2015, 282, 20151666. [CrossRef]

89. Leroy, T.; Louvet, J.-M.; Lalanne, C.; Le Provost, G.; Labadie, K.; Aury, J.-M.; Delzon, S.; Plomion, C.; Kremer, A. Adaptive introgression as a driver of local adaptation to climate in European white oaks. New Phytol. 2020, 226, 1171-1182. [CrossRef]

90. Holderegger, R.; Abbott, R.J. Phylogeography of the arctic-alpine Saxifraga oppositifolia (Saxifragaceae) and some related taxa based on cpDNA and ITS sequence variation. Am. J. Bot. 2003, 90, 931-936. [CrossRef]

91. Karrenberg, S.; Liu, X.; Hallander, E.; Favre, A.; Herforth-Rahmé, J.; Widmer, A. Ecological divergence plays an important role in strong but complex reproductive isolation in campions (Silene). Evolution 2019, 73, 245-261. [CrossRef]

92. Brochmann, C.; Xiang, Q.-Y.; Brunsfeld, S.J.; Soltis, D.E.; Soltis, P.S. Molecular evidence of polyploid origins in Saxifraga (Saxifragaceae): The narrow arctic endemic S. svalbardensis and its widespread allies. Am. J. Bot. 1998, 85, 135-143.

93. Jørgensen, M.H.; Elven, R.; Tribsch, A.; Gabrielsen, T.M.; Brochmann, C. Taxonomy and evolutionary relationships in the Saxifraga rivularis complex. Syst. Bot. 2006, 31, 702-729.

94. Böcher, T.W. The allotetraploid Saxifraga nathorsti and its probable progenitors S. aizoides and S. oppositifolia; Meddel. Grønland Biosci. 1983, 11, 1-22.

95. Wood, T.E.; Takebayashi, N.; Barker, M.S.; Mayrose, I.; Greenspoon, P.B.; Rieseberg, L.H. The frequency of polyploid speciation in vascular plants. Proc. Natl. Acad. Sci. USA 2009, 106, 13875-13879.

96. Vallejo-Marín, M.; Buggs, R.J.A.; Cooley, A.M.; Puzey, J.R. Speciation by genome duplication: Repeated origins and genomic composition of the recently formed allopolyploid species Mimulus peregrinus. Evolution 2015, 69, 1487-1500. [CrossRef] [PubMed] 
97. Mandáková, T.; Kovarík, A.; Zozomová-Lihová, J.; Shimizu-Inatsugi, R.; Shimizu, K.K.; Mummenhoff, K.; Marhold, K.; Lysak, M.A. The more the merrier: Recent hybridization and polyploidy in Cardamine. Plant. Cell 2013, 25, 3280-3295. [CrossRef] [PubMed]

98. Kapralov, M.V. Genotypic variation in populations of the clonal plant Saxifraga cernua in the central and peripheral regions of the species range. Russ. J. Ecol. 2004, 35, 413-416. [CrossRef]

99. Eidesen, P.B.; Ehrich, D.; Bakkestuen, V.; Alsos, I.G.; Gilg, O.; Taberlet, P.; Brochmann, C. Genetic roadmap of the Arctic: Plant dispersal highways, traffic barriers and capitals of diversity. New Phytol. 2013, 200, 898-910. [CrossRef]

100. Müller, E.; Eidesen, P.B.; Ehrich, D.; Alsos, I.G. Frequency of local, regional, and long-distance dispersal of diploid and tetraploid Saxifraga oppositifolia (Saxifragaceae) to Arctic glacier forelands. Am. J. Bot. 2012, 99, 459-471. [CrossRef]

101. Rieseberg, L.H. Homoploid reticulate evolution in Helianthus (Asteraceae): Evidence from ribosomal genes. Am. J. Bot. 1991, 78, 1218-1237. [CrossRef]

102. Lai, Z.; Kane, N.C.; Kozik, A.; Hodgins, K.A.; Dlugosch, K.M.; Barker, M.S.; Matvienko, M.; Yu, Q.; Turner, K.G.; Pearl, S.A.; et al. Genomics of Compositae weeds: EST libraries, microarrays, and evidence of introgression. Am. J. Bot. 2012, 99, 209-218. [CrossRef]

103. Ren, G.-P.; Abbott, R.J.; Zhou, Y.-F.; Zhang, L.-R.; Peng, Y.-L.; Liu, J.-Q. Genetic divergence, range expansion and possible homoploid hybrid speciation among pine species in Northeast China. Heredity 2012, 108, 552-562. [CrossRef] [PubMed]

104. Mao, J.-F.; Wang, X.-R. Distinct niche divergence characterizes the homoploid hybrid speciation of Pinus densata on the Tibetan Plateau. Am. Nat. 2011, 177, 424-439. [PubMed]

105. Mannocci, M.I.; Feretti, G.; Mazzoncini, V.; Fiorni, G.; Foggi, B.; Lastrucci, L.; Lazzaro, L.; Viciani, D. Two new Saxifraga species (Saxifragaceae) endemic to Tuscan Archipelago (central-northern Mediterranean, Italy). Phytotaxa 2016, 284, 108-130. [CrossRef]

106. Westergaard, K.B.; Jørgensen, M.H.; Gabrielsen, T.M.; Alsos, I.G.; Brochmann, C. The extreme Beringian/Atlantic disjunction in Saxifraga rivularis (Saxifragaceae) has formed at least twice. J. Biogeogr. 2010, 37, 1262-1276. [CrossRef]

107. Guldahl, A.S.; Gabrielsen, T.M.; Scheen, A.-C.; Borgen, L.; Steen, S.W.; Spjelkavik, S.; Brochmann, C. The Saxifraga rivularis complex in Svalbard: Molecules, ploidy and morphology. Flora 2005, 200, 207-221. [CrossRef]

108. de Storme, N.; Mason, A. Plant speciation through chromosome instability and ploidy change: Cellular mechanisms, molecular factors and evolutionary relevance. Curr. Plant Biol. 2014, 1, 10-33. [CrossRef]

109. Muellner-Riehl, A.N.; Schnitzler, J.; Kissling, W.D.; Mosbrugger, V.; Rijsdijk, K.F.; Seijmonsbergen, A.C.; Versteegh, H.; Favre, A. Origins of global mountain plant biodiversity: Testing the 'mountain-geobiodiversity hypothesis'. J. Biogeogr. 2019, 46, 2826-2838. [CrossRef]

Publisher's Note: MDPI stays neutral with regard to jurisdictional claims in published maps and institutional affiliations.

(C) 2020 by the authors. Licensee MDPI, Basel, Switzerland. This article is an open access article distributed under the terms and conditions of the Creative Commons Attribution (CC BY) license (http://creativecommons.org/licenses/by/4.0/). 